\title{
IMPROVEMENT OF MINE WATER TREATMENT TECHNOLOGICAL SCHEME BY IMPLEMENTING RAPID SAND FILTERS
}

\author{
Kulikova D.V., Kovrov O.S. \\ National Technical University "Dnipro Polytechnic" \\ D. Yavornytrskyi Avenue, 19, 49005, Dnipro \\ kulikova.d.v@nmu.one, kovralex1@gmail.com
}

\begin{abstract}
Mine water is polluted at all stages of the technological process. Its physical-chemical composition and properties are very diverse, vary significantly across coal basins, deposits and regions, and are formed under the influence of many factors. The constant transition of mining operations to deeper horizons leads to an increase in the volume and pollution rate by various chemicals in the water that taken along.

That is why mine water in most cases is not suitable for drinking water supply purposes and has properties that preclude its use for technical purposes or discharge into reservoirs without pre-treatment. With the help of existing mine water treatment technologies at coal mining enterprises, only large suspended solids can be retained, as a result of which insufficiently treated mine waters that do not meet the normative indicators of surface water quality enter the adjacent water ponds.

The paper deals with the improvement of the existing technological scheme of mine water treatment on the basis of their additional purification by a filtration method. It is proposed to install rapid sand filters with upward flow of liquid to the entire inflow at the final stage of pre-clarified mine water purification.

The implementation of the proposed technological scheme of mine water treatment at the coal mining enterprise reduces the content of fine suspended particles in the treated water to $5 \mathrm{mg} / \mathrm{l}$. This will allow, firstly, to use the treated water for the production needs of the mine and its own needs of treatment facilities, and, secondly, to discharge the excessive water into the adjacent surface water ponds, not exceeding the relevant standards of their quality. Key words: mine water afterpurification, suspended solids, clarifying ponds, filters with ascending fluid flow, surface water quality standards.
\end{abstract}

Удосконалення технологічної схеми очистки шахтних вод на основі впровадження швидких піщаних фільтрів. Кулікова Д.В., Ковров О.С.

Шахтна вода забруднюється на всіх стадіях технологічного процесу виробництва. Ї̈̈ фізико-хімічний склад і властивості дуже різноманітні, істотно змінюються за вугільними басейнами, родовищами і районами та формуються під впливом багатьох чинників. Постійний перехід гірських робіт на більш глибокі горизонти призводить до збільшення обсягів і забрудненості різними речовинами вод, що попутно забираються. Саме тому шахтна вода здебільшого непридатна для питного водопостачання і має властивості, що виключають її використання в технічних цілях або скид у водойми без попередньої обробки.

У зв'язку з наростаючим дефіцитом свіжої води і збільшенням кількості промислових стічних вод, що скидаються в прилеглі водойми, великого значення набуває питання очищення та використання останніх для технічного водопостачання. За допомогою існуючих методів на вугледобувних підприємствах технологій очищення шахтних вод можна затримати тільки крупні завислі домішки, внаслідок чого в прилеглі водні об'єкти надходять не досить очищені шахтні води, які не відповідають нормативним показникам якості поверхневих водойм.

У статті запропоновано вдосконалити існуючу технологічну схему очистки шахтних вод на основі їхнього доочищення методом фільтрування. Запропоновано на завершальному етапі очищення попередньо освітленої шахтної води встановити швидкі відкриті фільтри з висхідним потоком рідини на весь приток.

Впровадження запропонованої технологічної схеми очистки шахтних вод на вугледобувному підприємстві знижує вміст тонкодисперсних завислих частинок у доочищеній воді до 5 мг/л. Це дозволить використовувати доочищену воду на виробничі потреби шахти та власні потреби очисних споруд, надлишок можна скидати до прилеглих поверхневих водойм, не перевищуючи відповідних нормативів їхньої якості. Ключові слова: доочищення шахтних вод, завислі речовини, ставки-освітлювачі, фільтри з висхідним потоком рідини, нормативи якості поверхневих водойм.

Formulation of the problem. Any human activity is associated with the transformation of the natural environment, but the most large-scale transformation of nature is caused by mining, among which the first one is coal mining. The underground mining of coal causes a significant negative impact on the environment, which leads to significant changes in its ecological condition.

The most negative impact on the water ponds of coal-mining regions is caused by the discharge of waste waters by mining enterprises. This is due to their huge inflow rates, low quality in many respects that do not meet modern requirements of "The rules for protection of surface waters from pollution" [1], as well as the large-scale impact of coal mining processes on water ponds for a long time in a huge area. That is why mine water is a dangerous component of modern industrial production, which brings irreversible changes to the environment, deteriorating the quality of water in natural reservoirs.

Research topicality. Due to the growing shortage of fresh water and the increase in the amount of industrial wastewater discharged into adjacent reservoirs, 
the issue of treatment and use of the latter for technical water supply is of great importance. This will, on the one hand, reduce the use of drinking water for the needs not related to drinking and domestic water supply, and, on the other hand, improve the sanitation of surface and groundwater.

Despite the growing scientific and technical capabilities, the problem of surface water protection and, in particular, sanitary protection of water ponds from pollution by mine waters remains quite topical [2-3].

Relation of copyright work with important scientific and practical tasks. The application of the proposed and improved technological scheme of mine water treatment at the coal mining enterprise reduces the content of suspended solids after the first stage of purification in clarifying ponds to $30-50 \mathrm{mg} / \mathrm{l}$. After the second stage of purification in rapid open granular filters with ascending liquid flow, the content of fine suspended particles in the purified water is reduced to $5 \mathrm{mg} / \mathrm{l}$. This allows, firstly, to use it for the production needs of the mine and own needs of treatment facilities, and, secondly, the excess of treated water can be discharged to the adjacent surface water ponds, not exceeding the relevant standards of their quality.

Analysis of recent research and publications. Based on the requirements for water quality, the main methods of purification of mine water from suspended solids refer to sedimentation in settling tanks and clarifying ponds and filtering through a layer of granular material, mesh and fabric etc. The research works [4-8] and practical experience of mine water treatment shows that the applied methods of treatment and facilities have a certain efficiency, which is achieved with optimal technological parameters of the facilities and their proper operation.

The technological scheme with clarifying ponds can be effectively used for treatment of mine waters, in which suspended solids have good sedimentation properties, i.e. kinetically unstable and capable of coagulation without the introduction of chemical reagents (coagulants). In this case, the technically achieved quality of purified mine water after the clarifying pond on the content of suspended solids does not exceed 30-50 mg/1 [9].

The advantage of wastewater treatment technology using clarifying ponds is a combination of water clarification and sludge storage processes, simplicity of installation and operation, as well as high efficiency and reliability of their operation. Especially good results are obtained in the initial period: the water in the ponds is completely purified. Then, as the sediment accumulates, the cleaning efficiency decreases, the amount of suspended solids at the outlet exceeds the allowable concentrations and these waters can be used for domestic purposes only after additional treatment.

In [10-12] the results of researches on development of methods, both mechanical, and reagent purification of mine waters are resulted. Based on the performed research, depending on the properties of the source mine water and the requirements for the quality of treated, technological schemes of mine water treatment have been developed and implemented [13].

The difference in the composition and technological properties of mine water, on the one hand, and the requirements for the quality of treated water, on the other hand, does not allow choose one universal technological scheme, which in all cases would provide the required degree of purification and be the most economical.

Selection of previously unresolved tasks of the general problem. In practice, the purification of mine water from suspended solids is carried out using different methods and structures, which differ significantly from each other in efficiency and other technical and economic parameters.

Analysis of existing methods and means for reducing the level of environmental hazard due to discharge of contaminated mine water by coal mining companies into surface water ponds showed that it is possible to retain only large suspended impurities (coal particles and rocks) using of existing mine water treatment technologies. As a result, about $95 \%$ of insufficiently treated mine water are discharged into surface reservoirs, which leads to siltation of water ponds.

The purpose of the paper is to improve the technological scheme of mine water treatment on the basis of their additional treatment by filtration to effectively reduce the content of fine suspended solids to the normative indicators of surface water quality.

The research novelty refers to improvement of the technological scheme of mine water treatment at existing coal mining enterprises by installing fast open granular filters with ascending fluid flow to the entire inflow at the final stage of purification. It allows remove not only coarse suspended solids but also fine coal and rock particles from wastewater, the content of which can reaches $50-70 \%$ of the total mass of the dispersed phase.

Methodological or general scientific significance. Compliance with the "Rules of protection of surface waters from pollution by return waters" due to the implementation of the proposed technological scheme for mine water treatment allows show the ability of self-cleaning of reservoirs and watercourses in full, which leads to maintaining cleanliness and sanitation of adjacent areas.

Outline of the main material. The discharge of mine water into reservoirs is regulated by the "Rules for the protection of surface waters from pollution by return waters" [1]. First of all, the rules envisage the restriction of the discharge of such wastewater into reservoirs, which can be used in rational production technology through return water supply systems, as well as with the observance of the necessary sanitary requirements in agriculture.

According to the value of the maximum concentration of suspended solids in the water intended for use, all major consumers (technological processes and devices) can be divided into two groups. Group I includes techno- 
logical processes of wet coal beneficiation, preventive siltation and hydro-laying, prevention of spontaneous combustion and extinguishing of waste heaps, hydraulic extraction, hydraulic transport and boiler rooms (hydroash removal), group II - boiler rooms (steam production), stationary compressor and degassing units, conditioning facilities, dust removal equipment.

Group I consumers do not have high requirements for water quality in terms of the concentration of suspended solids and can consume mine water without preliminary treatment. Experience shows that the use of untreated mine water by these consumers in compliance with other indicators of chemical composition does not lead to any undesirable consequences.

The concentration of suspended solids in water intended for consumers of group II should be in the range of $5-30 \mathrm{mg} / \mathrm{l}$. Based on this, mine water can be used by consumers of group II, as a rule, subject to pre-treatment of suspended solids.

In general case, the technology of neutral mine water treatment includes a number of technological processes. In each case, depending on the composition and technological properties of mine water, the requirements for the treatment efficiency and the characteristics of the applied methods and devices, individual processes can be completely excluded from the technology or combined with other processes. In addition, the same technological processes can be carried out using different structures and devices in their design. These circumstances cause a great variety of technological schemes used in practice.

To compare them with each other and present technical and economic assessment, the general requirements for treatment technology and treatment facilities are developed. They are described as it follows [13]:

- purification technology should include 3 main stages: removal of suspended solids (or clarifying), disinfection of water, treatment (or storage) of sludge;

- removal of suspended solids should be carried out in one or two stages depending on their concentration in the source mine water;

- treatment technology must ensure the receipt of the required quality of treated water by changing the quantity and quality of source mine water according to the seasons of the year, as well as a result of opening new horizons and development of new areas of the mine field;

- the quality of mine water treatment should ensure the possibility of widespread use of treated water for production needs of enterprises and meet the conditions of discharge of excess volume into reservoirs;

- treatment plants should be reliable in operation, economical, easy to build and operate, as compact as possible and should not occupy large areas suitable for use in the national economy;

- technological processes of water purification and sludge treatment should be as amenable to mechanization, remote control and automation;

- the set of technological schemes of treatment should cover all possible range of change of inflows, structure and technological properties of mine waters.

Based on the analysis of the research results, practical experience in applying various technological schemes of mine water treatment and identifying compliance of these schemes with the above general requirements, the most modern and effective technological schemes of mine water treatment using clarifying ponds are selected and presented in the Table 1.

Technological schemes provide different degrees of mine water treatment. Purification from suspended solids is carried out in one or two stages. In two-stage technological schemes, depending on the specific conditions, the whole volume of mine water or only a part of it can be subjected to deep purification. Each technological scheme provides the set efficiency and is the most economic only in certain, characteristic for it conditions of application, at a certain structure and technological properties of mine water.

According to these technological schemes, wastewater treatment plants are designed to clean from suspended solids and disinfection of neutral mine waters with $\mathrm{pH}=6.5-8.5$ in order to use them for the manufacturing needs of the mine and neighboring enterprises, as well as to prevent water pollution due to discharge of excessive volume of mine waters.

The total concentration of suspended solids in the primary mine water is not limited. The content of fine particles with a hydraulic size less than $0.05 \mathrm{~mm} / \mathrm{s}$ should not exceed $50 \mathrm{mg} / \mathrm{l}$. The above mentioned methods

Conditions for the application of technological schemes using clarifying ponds and indices

Table 1 of cleaning efficiency [13]

\begin{tabular}{|c|c|c|c|c|}
\hline \multirow{3}{*}{ Manufacturing scheme } & \multirow{3}{*}{$\begin{array}{c}\text { Productivity } \\
\text { of treatment facilities, } \\
\mathrm{m}^{3} / \mathrm{hour}\end{array}$} & \multicolumn{3}{|c|}{ Concentration of suspended solids, mg/l: } \\
\hline & & \multirow{2}{*}{$\begin{array}{l}\text { in the primary } \\
\text { water }\end{array}$} & \multicolumn{2}{|c|}{ in purified water } \\
\hline & & & after $1^{\text {st }}$ stage & after $2^{\text {nd }}$ stage \\
\hline Large-capacity settling pond & not limited & not limited & $30-50$ & - \\
\hline Cascade of settling ponds & not limited & not limited & $20-30$ & - \\
\hline $\begin{array}{l}\text { Settling pond and quick filters } \\
\text { on part of the inflow }\end{array}$ & not limited & not limited & $30-50$ & $10-20$ \\
\hline $\begin{array}{l}\text { Settling pond and rapid filters } \\
\text { for the entire inflow }\end{array}$ & not limited & not limited & $30-50$ & to 5 \\
\hline
\end{tabular}




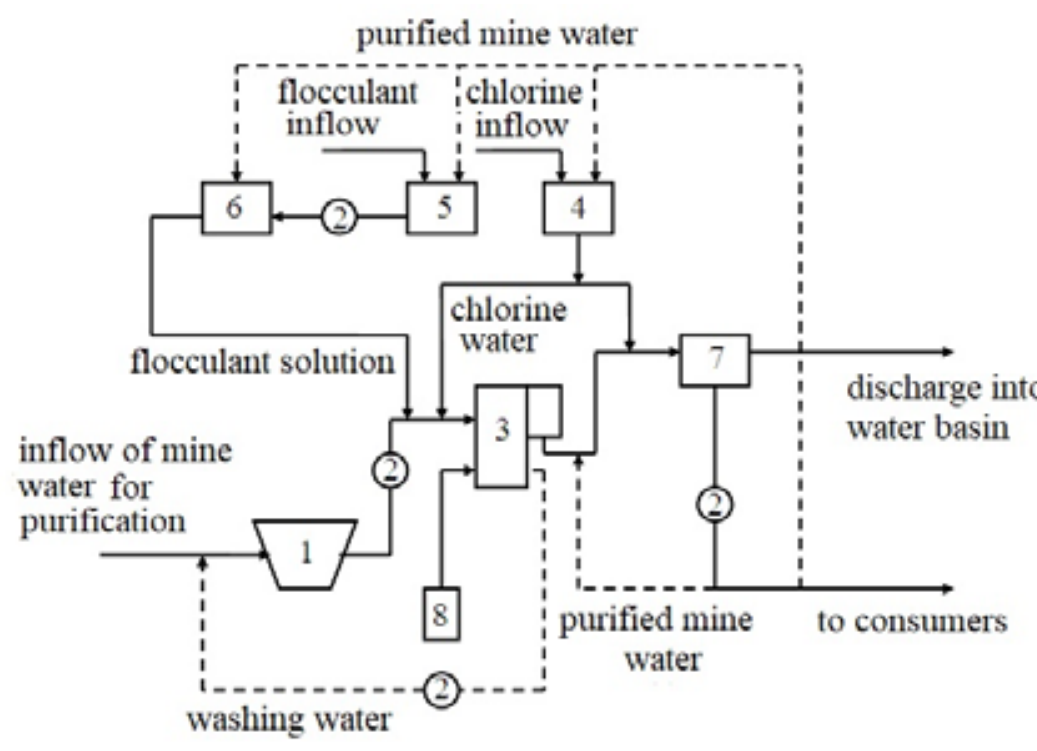

Fig. 1. Improved technological scheme for mine water treatment on the basis of afterpurification by filtration

1 - high-capacity clarifying pond; 2 - pumps; 3 -rapid filter; 4 - chlorinator; 5 -soluble flocculant tank; 6 -flocculant expendable tank; 7 -tank for purified mine water

for mine water treatment from suspended solids are the basis for the proposed application of an advanced technological scheme of mine water treatment.

When purifying mine waters at coal mining enterprises according to the existing technological scheme, which consists of a high-capacity clarifying pond, the water quality does not meet the standards required for fishery reservoirs regarding the content of suspended solids. Therefore, it was proposed to improve it by installing at the final stage of purification of pre-clarified mine water rapid open granular filters with upward flow of liquid to the entire inflow. In this case, the technically achievable quality of treated mine water on the content of suspended solids does not exceed $5 \mathrm{mg} / \mathrm{l}$. The capacity of water treatment facilities is not limited.

The improved technological scheme for mine water treatment on the basis of additional purification by the filtration method is presented in Fig. 1. In the proposed technological scheme, mine water enters the clarifying pond 1 of large capacity through a pressure or self-flowing pipeline. Then, after sedimentation it is taken by the pump 2 to the rapid open granular filters 3 . The content of suspended solids in preliminary clarified mine water before entering the filters is $30-50 \mathrm{mg} / \mathrm{l}$.

The main feature of the proposed scheme is the implementation of filtering pre-clarified mine water in the direction of decreasing grain size of the filter loading along the stream (bottom up). As a result, the dirt removal capacity of the filter and the duration of the filter cycle increases, and the possibility of siltation of fine-grained layers of filter loading is excluded.

In order to improve the quality of water purification, its filtration can be carried out by pre-treatment with a solution of flocculant. Polyacrylamide (PAA) is used as a reagent to reduce the amount of precipitate. Preparation of a concentrated solution of flocculant takes place in a soluble tank 5 with mechanical stirring. From the soluble tank 5 , the concentrated flocculant solution is pumped by the pump 2 into the flow tank 6 , diluted in it to the working concentration and dispensed by means of a float dispenser into the mine water to be purified before it enters the filters.

The filters are flushed with purified mine water from the tank 7 by means of a special pump and air from a blower. Contaminated flushing water by pump 2 is supplied for treatment to the clarifier pond in conjunction with the source mine water. The filtrate of purified mine water is mixed with chlorinated water produced in the chlorinator 4 , and followed to the tank of purified water 7 for disinfection. The treated water from the tank is used for the manufacturing needs of the mine and the own needs of the treatment facilities. Excessive amount water is discharged to adjacent water reservoirs.

The advantages of the improved technological scheme of mine water treatment based on filtration method include the following:

- it can be used in a wide range of mine waters inflows;

- it provides high quality of purified mine water regardless of the initial concentration of suspended solids, which allows its widespread use for the manufacturing needs of enterprises;

- to achieve high quality cleaning, it is sufficient to use one reagent (usually a flocculant), which simplifies the reagent facilities;

- dewatering and sludge storage is combined in one building with the clarifying of the source mine water and does not require large operating costs;

- wastewater treatment plants are easy to build and operate and characterized by the lowest specific capital operating costs.

Conclusions. The actual practical problem is solved in the paper, which consists in improvement of the technological scheme for mine water purification due to installation of rapid open granular filters with ascending liquid flow on all inflow at the final stage of purification.

The implementation of the proposed technological scheme of mine water treatment at the coal mining enterprise reduces the content of suspended solids in the water after the first degree of purification in the clarifying ponds to $30-50 \mathrm{mg} / \mathrm{l}$. After the second stage of purification in rapid open granular filters with ascending liquid flow, the content of fine suspended particles in the purified water is reduced to $5 \mathrm{mg} / \mathrm{l}$. 
Perspectives for the further use of research results. the content of fine particles of slurry. It allows, first, use The implementation of an advanced technological purified water for manufacturing needs and own needs scheme for mine water treatment by installing rapid open of treatment facilities, and, second, the discharge excesgranular filters with ascending fluid flow to the entire sive water into adjacent surface water ponds without inflow at the final stage of purification effectively reduces exceeding the standards of environmental quality.

\section{References}

1. Про затвердження Правил охорони поверхневих вод від забруднення зворотними водами : Постанова КМУ від 25 березня 1999 року. № 465. Офіиійний вісник Украӥни. 1999. № 13.

2. Kulikova D.V., Pavlychenko A.V. (2016). Estimation of ecological state of surface water ponds in coal mining regions as based on the complex of hydrochemical indicators. Naukovyi Visnyk Natsionalnoho Hirnychoho Universytetu, (4), 62-70.

3. Gorova A., Pavlychenko A., Kulyna S., Shkremetko O. (2013). The investigation of coal mines influence on ecological state of surface water ponds, Annual Scientific-Technical Colletion Mining of Mineral Deposits. Leiden, The Netherlands : CRC Press / Balkema, p. 303-305.

4. Харионовский А.А. Комплексная очистка шахтных и карьерных вод от техногенных загрязнений. Шахты : Изд-во ЮРО АГН, 2000. $238 \mathrm{c}$.

5. Виговська Д.Д., Виговський Д.Д., Пікульова Т.П. Технологічні особливості очищення шахтних вод. Вiсті Донеиъького гірничого університету. № 1(30)-2(31). 2012. С. 78-83.

6. Гулько С.Е., Гомаль И.И. Анализ состава и состояния гидротехнических сооружений угольных шахт. Bicmi Донец̧ького гірничого університету. № 1(32). 2013. С. 78-84.

7. Кривощеков В.И., Чутчева А.Г. Проблема очистки шахтной воды и направление ее решения. Збагачення корисних копалин. Вип. 55(96). 2013. http://zzkk.nmu.org.ua/pdf/2013-55-96/11.pdf.

8. Ворон Л.В., Ланге Л.Р., Благоразумова А.М. Проблемы очистки шахтных вод. Вестник Сибирского государственного индустриального университета. № 2(12). 2015. С. 76-79.

9. Горшков В.А. Очистка и использование сточных вод предприятий угольной промышленности. М. : Недра, 1981.269 с.

10. Витренко Л.М., Сергиенко С.Ф. Очистка шахтных вод от грубодисперсных примесей. Научные труды ВНИИОСуголь «Очистка и использование шахтных вод». Вып. XVI. 1973. С. 29-36.

11. Витренко Л.М., Сергиенко С.Ф. Новые технологические схемы очистки шахтных вод в Донбассе. Hayчные труды ВНИИОСуголь «Очистка и использование шахтных вод». Вып. XVI. 1973. С. 73-85.

12. Kolesnyk V., Kulikova D., Kovrov S. (2013). In-stream settling tank for effective mine water clarification In: Annual ScientificTechnical Collection "Mining of Mineral Deposits". CRC Press/Balkema, Netherlands; Taylor \& Fransis Group, London, UK. P. 285-289.

13. Технологические схемы очистки от взвешенных веществ и обеззараживание шахтных вод : каталог. Пермь : ВНИИОСуголь, 1986. 69 c. 